\title{
GENRE-SPECIFIC FEATURES OF THE SHORT STORY IN SERBIAN REALISM
}

ABSTRACT. This paper will discuss genre-specific features of the short story in Serbian Realism. To establish genre-specific, primarily linguistic and stylistic features of the short story in Serbian Realism and prose in general, we will describe stylistic attributes that connect literary works written in the period of Realism as a movement and determine common stylistic features that link them. In addition, we will also examine the status of the prose text, the creative method of which was defined as realist in contemporary Serbian literature. Conclusions indicate that the structure of the auctorial short story is not subject to strict theoretical rules and that the term realist short story does not restrict the story to the period of the epoch of Realism, but allows it to apply to every literary period in which authors used the objective method to depict events and protagonists.

KEY WORDS: genre-specific features, Realism, language, style, short story.

1 mirjanastakic073@gmail.com

This paper was submitted on April 16, 2016 and accepted for publication at the meeting of the Editorial Board held on September 29, 2016. 


\section{INTRODUCTORY REMARKS ON REALISM AS AN ART MOVEMENT}

The time of the emergence of the auctorial short story and association with a particular literary period go hand in hand with some genre-specific characteristics. Serbian realist short story owes its characteristics to the epoch of Realism within which it was created and developed as an individual form of artistic prose. It is impossible to analyze its linguistic and stylistic features without a short overview of the period of Realism within which it emerged and developed.

It is hard to determine when exactly the period of Realism began. ${ }^{2}$ Certain attributes of Realism can be found in English novels of the 18th century. Realism (nominally) appeared in the mid-19th century, at the time when Romanticism was already past its prime. However, the first realist authors lived in created in the second third of the 19th century. Social circumstances were such that they required greater precision and accuracy in the observation of phenomena. It was the period of the rise of citizenry and they adopted the positivist approach and analysis of fact as their core philosophy, in accordance with the development of natural sciences and rapid development of capitalism. The imperative of the period was to make art a faithful image of social relations, conflicts and progression. Civil society could no longer express itself artistically through romanticist revelries. All this laid the foundations for the development of Realism, and a whole range of artists articulated the principles of this movement which can be united under a single formula: to depict and express reality as genuinely as possible (Mala enciklopedija Prosvete, 1968).

In Serbian literature, Realism appeared as an art movement in the early 1870s, whereas 1880 s are the period when Glišić writes his stories, Laza Lazarević's novellas are published, as well as the works of Matavulj and Janko Veselinović. Stevan Sremac and Svetolik Ranković published their most important works in the 1890s. The epoch of Realism begins with the revolutionary, democratic

2 Early Realism bears traces of the Romantic style and some of its representatives considered themselves romanticists, whereas some works written in the period of transition from one movement to another are still the subject of discussion, i.e. whether they belong to Romanticism or Realism (Pushkin's Eugene Onegin, Lermontov's A Hero of Our Time). 
and socialists ideas of Svetozar Marković. Deretić finds the parallel between the movement and the "basic tendencies of socio-economic development" (Deretić, 1979, p. 17). In the name of science, Marković demands that literature "present only what is truly useful for the society: to raise and discuss contemporary issues, to faithfully depict people's lives from the standpoint of modern science, in a nutshell, to be contemporary in its thoughts and feelings" (Marković, 1963, pp. 7-8). In the root of these attitudes lay a utilitarian view of literature, a demand for social tendentionality and social engagement of the author. Marković wrote that there is no difference between an artist and a scientist, because the creative process of both is identical; they think, analyze, study facts - the only difference is the study subject. The latter studies matter, whereas the former studies his emotions. If the purpose of literature is viewed like that, then it had little use for aesthetics, which is why Pera Todorović negates aesthetics as the science of beauty in his brochure Destroying Aesthetics (1882). According to him, aesthetics would be relevant only if the beautiful has a meaning of its own that wouldn't depend on the variety of personal taste which is infinite.

The dominant feature of social relations in the Serbia of that period was the conflict between the patriarchal society and forces that strived to strengthen the state and statehood, so the first development phase of Serbian Realism is characterized as "journalistic-critical" phase by Vučenov. After this phase, Serbian literature focused on depicting the country life. Short story about rural life became the dominant literary genre, and its rusticity major attribute, so Vučenov calls this period "the phase of rustic prose". It prevailed in Serbian prose for almost a quarter century, until the end of the 19th century when it started to manifest exhaustion. This phase was succeeded by the final phase of Serbian Realism, "the phase of provincial topics" (Ibid. p. 27). The approach to provincialism and provincial life started with a humorous tone, which, according to Vučenov, stemmed from two perspectives. The first perspective is found in the works of authors who were born in the country themselves, who originated from a rustic environment. The second perspective, used by Serbian Realism to humorously depict the provincial environment and mentality, was the perspective of the urban intelligentsia and artistic bohemian population. Bohemian population was mentally the complete opposite of the provincial nature and small-mindedness, so their humorous and 
satirical view of the provincial life and provincial persons is understandable (Ibid. p. 29). The same author also points out to a different form of patriarchy called the "chorbaji-craftsmen" 3 class (Ibid, p. 31). This class is characteristic of those Balkan regions in which the Oriental atmosphere lingered, together with remains of the Ottoman regime. It is characterized by a complex scale of feelings and experiences, much more extensive than patriarchal rustic life. The rich gamut of human destinies in prose encompasses characters whose fame, fortune and reputation are past their prime and are on the downward path, so the depiction of the province and provincial life, which began with humorous tones in Serbian realist prose, ended with descriptions of the tragic experience of life.

We can summarize that the period of Serbian Realism never reached real urban life, only provincial and rustic life. Serbian realists started from progressive socialist and democratic tendencies of Svetozar Marković and his supporters, only to reduce their demands in the rustic phase of Realism to ideological and artistic engagement of the author in defense of the patriarchal rural environment and the old ways and relations based on the centuries of tradition before the onslaught of modern life. The image of provincial life in Serbian prose is more diversified than the image of rural life, richer and more linguistically complex. Social engagement of the realist seems to diminish, writing is more objective and aesthetic aspirations take precedence over ethical aspirations.

\section{GENRE-SPECIFIC CHARACTERISTICS OF THE (SERBIAN) REALIST SHORT STORY}

Realism accomplished its greatest achievements in prose, which is understandable, given that realists strived to depict as much of the social and domestic reality of their time as possible. Novel occupies the most prominent place, and other narrative forms developed from it: short story, novella and the sketch story. One of the basic elements of epic fiction, the plot, partially loses its significance, so if authors of pre-Realism wrote about doomed love affairs, kidnappings, murders, poisonings, and intrigues, realists subordinated the plot to character exposure. Speaking about the weakening of

3 Title for (Christian) members of the rural elite, heads of villages and other rural communities and rich peasants during the reign of the Ottoman Empire. 
the plot in realist prose, Flaker underlines that the plot loses its significance as "a major constituent element of the structure" in Realism and that realists reduce and subject the plot to "the fundamental process of Realism - character exposure (Flaker, 1976, p. 154). Pantić singles out one conclusion from the Flaker's quotation, that "realists promoted summary as a separate element of prose structure, which was noted by Russian formalists in the early 20th century" (Pantić, 1982, p. 105).

The purpose of weakening the plot is to expose the character of the literary hero in the unity of his social, psychological and intellectual being. Starting from the representativeness of the character for specific socio-psychological states, Realism developed a theory of typicality and the principle of typization as the general aesthetic formula. ${ }^{4}$ Establishing relationships with other characters, the hero of a realist prose work manifests psychological and ideological attributes and reveals a significant social or ethical issue of his time. The emphasis is on the socio-psychological motivation behind hero's actions. An element closely related to developed socio-psychological motivation are descriptions, specific and detailed. They are highly functional within the plot or characterization of the protagonist (e.g. descriptions of nature, urban environments, interior of houses and apartments), subject to character formation and they become independent in Naturalism. Realists observe the surroundings are the environment, and the environment especially exteriors can be viewed as metonymic or metaphorical expressions of protagonists' characters. Stakić indicates that the detailed description of the Vauquer boarding house in Balzac's Perè Goriot (Balzac, 2005) expresses the characters of its residents, primarily Perè Goriot himself, because it reflects the extent of his poverty (Stakić, 2015).

When it comes to the short story as a literary genre that achieved its full domination in the period of Realism, we can say that in Serbian literature, it carries thematic and formal characteristics of the epoch to which is belongs: it is predominantly thematically oriented toward rural life, and stylistically, it emphasizes folk speech. Vukićević points out that folk literature was recognized

4 The attitude of modern literary criticism is that a literary character should not be treated as a collection of permanent and unambiguous characteristics. It is mutable in its development, and governed by its socio-psychological determinants, by manifesting different attributes alternately, establishing relationships with other characters. 
and singled out as a major poetic (thematic, stylistic, genre-specific and narrative) foundation in the development of the short story (Vukićević, 2006). Serbian realist short story is characterized by the faithful representation of life. ${ }^{5}$ The author's powers of observation are emphasized in the thematic structure through the identification of details inextricable from the life of the patriarchal Serbian village. The interest for the national, ethnographic, folk and rustic aroused by Romanticism is thematically expanded. Prose expression is also subject to thematic elements, and shaped by the creation of socio-psychologically motivated characters, which means that it is socially motivated by the personality of the narrator or protagonists in the dialogues. This is why the language of different characters is differentiated by their class, professional and ethical characteristics, and the narrative fiber also includes jargon, local words and professional slang. For example, Glišić is famous for allowing his protagonists to speak the way they did at home, in the field, or in the tavern. His peasants have a lively, dynamic and suggestive manner of speaking. "As representative of the simple and uneducated class, they use the language which is often grammatically incorrect and deviates from the norm, which only reinforces the impression of realism and creates an illusion of oral storytelling" (Stakić, 2014, p.125). Violation of the linguistic norms may also occur as the consequence of the imitation of oral narrative, or as the consequence of mimicking oral folklore. Narrators had a more flexible attitude toward the conversational style, because things that were redundant in folklore could have a certain stylistic value nonetheless (Vukićević, 2006).

We can observe the use of archaic words for describing the plot, scenes, nature, and in characters' dialogues and monologues in the same context. Archaisms vividly evoke the time and the atmosphere of the plot, especially if the narrative occurs during the 18th and the 19th century. Serbian realist short story frequently uses loanwords, especially from Turkish, due to the Oriental character of the rural culture, which is the consequence of the aforementioned socio-historical circumstances. Hence, Glišić's peasant will

\footnotetext{
In the Serbian realist short story, we have the domination of the event and the use of descriptive narration in the exposure of events and human characters. Some realists, such as Laza Lazarević, deviate from this rule, because in his opus, the purpose of the plot is to expose characters with an emphasis on the psychological motivation behind their actions.
} 
say "âdet" instead of custom, he will call a lucky man "batli" (?anslı), and hang a "yatağan" instead of knife from his belt.

The believability and force of the prose expression are achieved through the use of figures of speech, primarily epithets, comparison, contrast, gradation, personification and onomatopoeia. We have a highly distinctive and picturesque description of nature in the Kočić's short story Through the Storm. By giving human attributes to natural phenomena, furious winds, howling hurricanes, sharp and biting cold, Kočić has created a striking image of the winter landscape and the blizzard, allowing his readers to experience it with almost all senses.

"Somewhere in the distance, the howling of hungry wolves that chills the blood echoed from the mountain tops through the restless night, mingling with the roar and crashing of raging winds that shook the earth, which carried enormous snow drifts on their strong backs like invisible giants, madly scattering them around...The winds howled, howled and roared, and the half-dead lips kissed and sighed, surrendering to sweet death..." (Kočić, 1980, p. 151).

In addition to the great suggestive power of this description, its functionality reflects in the revelation of the heroes' fate. A terrible storm, with personified forces of nature behaving like beasts, shows that man is weak and inevitably doomed to failure in his struggle against nature, which in Kočić's short story means physical death, i.e. freezing.

\section{REALISM AS A CREATIVE METHOD AND CONTEMPORARY PROSE}

The term realistic prose can be applied conditionally to prose works with the predominant realist method. In that sense, we still have authors who write realist narrative fiction, although contemporary prose has moved away from the narrative Realism of the 19 th century, especially in the years after World War II. Reasons for this can be found in circumstances that significantly changed in relation to the 19th century. The prevailing feeling of modern man is loneliness and alienation that occur due to the faster pace of life, automation of human relations, destruction of the existing value system and economic uncertainty. Contemporary writers, faced with such changes, are forced to change their approach to creativi- 
ty, and those changes are primarily felt in the domain of language and style of literary works. Poniž puts special emphasis on language differences between traditional (realist) and contemporary prose. He calls the first type realist prose and believes that this prose is written with activist language which is by nature less complex, and therefore easier to comprehend and interpret. It can be a vernacular or a local dialect that the reader can understand, which gives him a strong feeling of security. On the other side, we have ideologically unencumbered prose that opens new worlds. Authors of such prose mix elements of the traditional and the avant-garde, condensing the form and utilizing parody. Language becomes the reality of such prose, language that is artistic and maintains communication with the reader even after he finished reading the book (Poniž, 1981, pp. 26-33).

Talking about the development of German literature, Martini outlined the development path of modern prose. He indicated the absence of a common style, destruction of the continuity of tradition and domination of the individual, personal stamp of certain authors. Authors adopted an increasingly technological and methodological approach to creative work. The boundaries between forms are erased, and there is a sharp breakup with literary tradition. Literary expression in prose is focused on the language of symbols and codes, parabolas, fragmentation, open, undefined and ambiguous perspectives. All this forces authors to turn to detail, fragment and individual structures. Authors are no longer biased or impartial observers of events. A modern prose writer looks inside, he is obsessed with his ability to say, describe or remain silent (Martini, 1971, pp. 634-640). Albahari shares a similar attitude. He quotes the American literary critic Joe David Bellamy in his study of contemporary short story, who thought that in traditional prose, "we have protagonists who look outside - toward society, human actions, plots", whereas in modern prose from the early 20th century, "we observe things from inside the protagonist who look outside", or most commonly, "in the world of a contemporary super-author, we observe the world from the inside of an inwardly-oriented person" (Albahari, 1998/99, p. 463).

Orientation of modern prose toward the language and form came to the fore in the most compressed genre - short story. Contemporary short story completely deviates from the model of realist narration, because it shifts the center of interest from objective reality toward the work itself and the process of its creation. It is 
characterized by the tendency toward form compression and mixing of narrative procedures and parodies.

In the Albahari's short story A Walk by the River (Albahari, 2004), through the dialogue of main protagonists: the boy narrator, father, mother, Ruben Rubinović and cousin Sarina, we discover a new modern form of artistic short story. The modern short story is characterized by a reduced sentence and compressed expression, but the compression of words doesn't mean the directness of thoughts, but complex ambiguity. In the aforementioned story, we have one of the postmodern thoughts that all stories been already told, and that the only thing we can do is to interpret them differently. Postmodernism rejects the idea of an end, because the end of the plot of one literary process means the birth of another artistic process and a new poetic that will restore what was told and make it artistically relevant through interpretation. Analyzing Albahari's literary opus, Gvozdenov observes that it "refuses to develop the plot" which "represents an attack on art, because while we admire the external form, we forget lasting inner traumas" (Gvozdenov, 2015, p. 12).

We will use the prose of Miomir Milinković to present the model of contemporary Serbian realist short story. In his collection of short stories A Step toward the Sky (Milinković, 2016), each of seven stories is a unit of its own, but they are connected by a broad scale of deviations and negativity that exist in modern society, manifesting through conflicts that main protagonists get themselves in because of their egotism, greed, vanity and alienation. What makes this work a part of modern prose is psychoanalytical exposure of internal processes that occur in the protagonist's conscious and subconscious mind. The author uses dreams to reveal intrinsic motivation and conflicts related to suppressed internal conflicts. Milinković presented motives that drive and guide the behavior of his characters from the standpoint of the philosophy of the absurd and depicted them with an irony that shows individual and collective nature of our urban civilization, which also seems to be on the decline. The purpose of expressiveness of the language, functionality of descriptions and guiding the plot toward the culmination of the conflict and the psychological consequences of its resolution is a strong condemnation of moral decline the modern man is willing to suffer in order to fulfill personal interests. However, the core of this prose lies in the realist method of depicting the presented advantage. Functionality of 
descriptions, the power of observation and dedication to detail, even the characters' names are there to explain the sociological and psychological motivation and characterization of the protagonists and the realist method in the depiction of the presented reality. Even when he penetrates the character's subconscious with the use of psychoanalytical methods, the author applies the realist method.

In the short story The Case of Mr. Tiodor Stević, the dream in which the hero assembles parts of numerous detached jaws on skeletons in the cemetery, the faithfulness of the description causes nausea not only with the dreamer, but the reader as well.

"One jaw was stuck and turned sideways, so he couldn't fit it back in.

When he pushed harder, the jawbone snapped and broke in two"

(Milinković, 2015, p. 29).

CONCLUSION Auctorial short story as a literary genre is not a closed and isolated form. Although its form, structure and style change depending on the historical and social context of the period in which it was written and the literary conventions dominant for that period, short story is not subject to strict theoretical rules. Even today, in the period of Postmodernism, authors still write short stories similar to those written in the 19th century. If we observe it in this context, realist short story could not be restricted to the duration of the epoch of Realism, but applies to every literary period in which authors used the objective method for the depiction of events and characters. In conclusion, the term realist short story can be observed in two ways:

1) as the short story written in the period of Realism with all the accompanying characteristics of this epoch,

2) or as the short story with the dominant realist method in the depiction of the world and objective reality.

REFERENCES Алठахари, Д. (1998/99). „Савремена кратка прича”. У: Љиљана Николић и Босиљка Милић (прир.), Лекӣира за IV разреg іимназија и среgюих сйручних школа (стр. 462-466). Београд: Стручна књига.

Албахари, Д. (2004). Ойuс смрӣu. Београд: Српска књижевна задруга.

Балзак, О. (2005). Чича Горио. Београд: Просвета.

Блекбурн, С. (1999). Оксфорgски филозофски речник. Нови Сад: Светови.. 


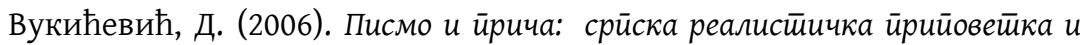
фолклорна йраguициа. Београд: Друштво за српски језик и књижевност Србије.

Вученов, Д. (1981). Траїом ейохе реализма. Крушевац: Багдала.

Гвозденов, В. (2015). „Романопишчева опклада”. У: Д. Албахари, Мамац / Цинк, Изабрана дела Давида Албахарија, први том (стр. 11-13). Београд: Чаробна књига.

Деретић, J. (1979). „Српска књижевност и историја”. У: Бранислав

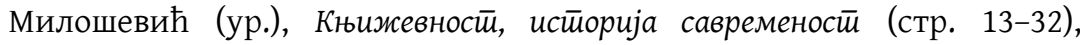
Београд: Рад.

Кочић, П. (1980). „Кроз мећаву”. У: П. Кочић, Оgабрана gела (138-151). Београд: Рад.

Мала енцииклойеguја Просвет̄е (1968). Београд: Просвета.

Марковић, С. (1963). Певање и мишљење. Београд: Рад.

Мартини, Ф. (1971). Истиорија немачке књижевносӣи. Београд: Нолит.

Милинковић, М. (2015). „Случај господина Тиодора Стевића”. У: М. Милинковић, Корак gо неба (19-36). Легенда: Чачак.

Пантић, М. (1982). „Сижејне доминанте Лазаревићевих приповедака”. Књижевносии и језик, 2, 105-118.

Пониж, Д. (1981). „Традиционализам и модернизам, дијаспора појмова и културно торбарење савременом словеначком прозом". Граguна, 2, 26-33.

Стакић, М. (2014). „Поетски језик као одлика стила књижевне прозе”, 3ठорник радова Учитељског факултета, књига 8, стр. 123-137.

Стакић, М. (2015). „Улога и значај карактеризације у тумачењу

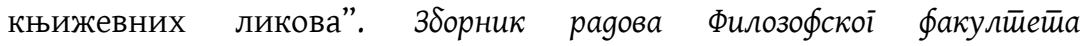

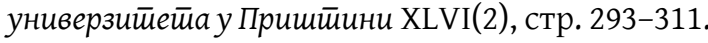

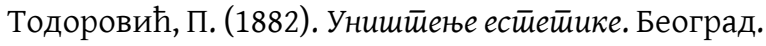

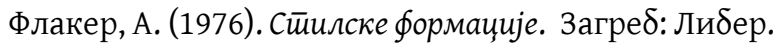


МИРЈАНА М. СТАКИЋ

УНИВЕРЗИТЕТ У КРАГУЈЕВЦУ

УчИТЕљСКИ ФАКУЛТЕТ У УЖИЦУ

РЕЗИМЕ

ЖАНРОВСКЕ СПЕЦИФИЧНОСТИ

СРПСКЕ РЕАЛИСТИЧКЕ ПРИПОВЕТКЕ

У раду разматрамо жанровске специфичности српске реалистичке приповетке. Да бисмо утврдили жанровске, првенствено, језичкостилске особености српске реалистичке приповетке и прозе уопште, описујемо стилске специфичности које повезују реалистичка дела настала у време развитка реализма као правца; утврђујемо заједничке стилске црте које их повезују и разграничавамо њихове стилске карактеристике у односу на оco反eности прозних текстова који припадају претходном периоду романтизма. Такође, истражујемо и у савременој српској књижевносности статус прозног текста који у стваралачком методу носи ознаке реалистичког. Закључци упућују да структура ауторске приповетке не подлеже строгим теоријским правилима и да термин реалистичка приповетка не ограничава приповетку само на време трајање епохе реализма, већ на сваки књижевни период у коме је стваралац користио објективни метод у приказивању догађаја и јунака.

Кључне речи: жанровска специфичност, реализам, језик, стил, приповетка. 